\title{
Time Management Practices, Character Development and Academic Performance among University Undergraduates: Covenant University Experience
}

\author{
Elizabeth I. Olowookere1, Amos A. Alao' ${ }^{1}$, Jonathan A. Odukoya1, Olujide A. Adekeye1, \\ Godwyns Ade' Agbude 2 \\ ${ }^{1}$ Department of Psychology, School of Human Resource Development, College of Leadership Development \\ Studies, Covenant University, Ota, Nigeria \\ ${ }^{2}$ Department of Political Science and International Relations, College of Leadership Development Studies, \\ Covenant University, Ota, Nigeria \\ Email: elizabeth.olowookere@covenantuniversity.edu.ng, amos.alao@covenantuniversity.edu.ng, \\ adedayo.odukoya@covenantuniversity.edu.ng, olujide.adekeye@covenantuniversity.edu.ng, \\ agodwins1@yahoo.com, godwyns.agbude@covenantuniversity.edu.ng
}

Received 2 January 2015; accepted 20 January 2015; published 26 January 2015

Copyright (C) 2015 by authors and Scientific Research Publishing Inc.

This work is licensed under the Creative Commons Attribution International License (CC BY). http://creativecommons.org/licenses/by/4.0/

c) (i) Open Access

\section{Abstract}

Background: University undergraduates are representative of the Nigerian youth population; and sustainable development in any nation depends on the resourcefulness of her youth. This necessitates the need to drive excellence among Nigerian undergraduates through quality education and advice. Quality education is demonstrated in character and in learning; and characters of discipline, responsibility and diligence serve as the hallmark of excellence among university undergraduates. It is hypothesized that time management practices will be positively related to character development and academic performance among university undergraduates. Method: The case study and ex-post facto research designs were adopted in this study. Questionnaire was administered to 120 Diploma and Certificate students of Leadership Development Programme in Covenant University. Results: The findings revealed a positive relationship between character development and time management practices $(r=.44, p<.01)$ and between character development and academic performance $(r=.23, p<.05)$. The result further revealed that time management practices predicted character development $\left(R^{2}=.241, \mathrm{~F}(3,116)=12.383, p<.01\right)$ and character development predicted academic performance $\left(\mathrm{R}^{2}=.241, \mathrm{~F}(3,116)=5.412, p<.01\right)$. However, no significant relationship was found between time management practice and academic performance $(r$ $=.18, p>.05$ ). Conclusion: It was concluded that in the quest for academic excellence, building 
performance characters such as discipline, responsibility and diligence among university undergraduates was as important as improving the quality and standard of learning. This study therefore recommended that time management training be incorporated into academic advising and tutoring programs in the Nigerian academia.

\title{
Keywords
}

\author{
Time Management Practices, Character Development, Academic Advising, Self-Regulation, Youth, \\ Undergraduates, Nigeria
}

\section{Introduction}

Nigeria has a population of 140 million people (NPC, 2006) with one third of her population between the ages of 10 to 24 years (Second Nigeria National Youth Policy, 2009). According to Nigerian National Youth Policy (2001), persons within the age range of 18 to 35 years belong to the youth population. Most persons in this category are in the tertiary institution. Therefore university undergraduates may be considered as representative of the Nigerian youth population. The youth represent the strength and future of any nation state. They are the drivers of sustainable growth and development in the nation.

Nations depend on tertiary institutions to convert her youth into resourceful and formidable workforce, capable of transforming the economy and taking up the leadership of the nation. This has left Universities with the responsibility of producing "total man" graduates found worthy both in character and in learning. The total man concept is used to describe self-regulated individuals motivated by excellent performance and matchless impact in their immediate and global environment. Despite this enormous task, Nigerian Universities are still struggling with poor academic performance and misconduct among their students. This is partly because most institutions have paid greater attention to fostering learning rather than building those characters needed to facilitate the learning process and to sustain what is learned. Bello and Amali (2012) identified the goals of education to include helping young people become academically sound and to emerge as good citizens of their countries. Furthermore, Oredein (n.d) suggested that a good foundation of self-discipline and moral character is necessary for good conduct and development among the youths. This implies that both performance character and moral character are needed for the progress of the Nigerian youth.

Students need to develop self-regulatory processes in order to maximize the benefits of education and become great assets to the society. In this context, self-regulation was defined by Zimmerman (1998) as self-generated thoughts, feelings, and actions directed towards the achievement of set academic goals. It describes the proactive efforts made by students to learn on their own, demonstrate personal initiative, resourcefulness and sense of responsibility (Zimmerman, 1998). These self-regulatory processes are essential for improved academic performance. These processes may be associated with the development of performance characters among students.

Britton and Tesser (1991) noted that time management variables have been implicated in self-regulated learning. Similarly, Zimmerman (1994) as cited in Zimmerman (1998) identified self-regulatory processes to include time management, goal setting, task strategies, imagery, self-monitoring, self-evaluation, self-instruction and self-consequences, environmental structuring and help seeking. Some of these other self-regulatory processes are entwined in effective time management practices and hypothesized to foster the development of performance characters such as discipline, diligence and a sense of responsibility. Davidson, Khmlekov and Baker (2011) defined performance character as consisting of the qualities that allow individuals to regulate their thoughts and actions in ways that support achievement in a particular endeavour. The self-regulatory processes are illustrated in Table 1.

Students have multiple tasks and multiple instructors to satisfy, and grades are determined by the quality of work submitted to these different instructors. Time-management practices have been found to predict college achievement (Britton \& Tesser, 1991). However, the development of such skills has not been effectively incorporated into academic advising and tutoring in Nigerian Universities. According to Zimmerman (1998), teachers have neglected the teaching of necessary study skills like time management in their effort to encourage study habits among students. The current study hypothesized that a connection exists between time management 
Table 1. Students' self-regulating processes.

\begin{tabular}{cll}
\hline S/N & Self-regulatory processes & \multicolumn{1}{c}{ Example of student behaviour } \\
\hline 1 & Goal setting & Making lists of tasks to accomplish during studying \\
2 & Task strategies & Creating mnemonics to remember facts \\
3 & Imagery & Imagining the consequences of failing to study \\
4 & Self-instruction & Rehearsing steps in solving a math problem \\
5 & Time management & Scheduling daily study and homework time \\
6 & Self-monitoring & Keeping records of completed assignments \\
7 & Self-evaluation & Checking work before handing it to the teacher \\
8 & Self-consequences & Making TV or telephone calls contingent on homework completion \\
9 & Environmental structuring & Studying in a secluded place \\
10 & Help seeking & Using a study partner \\
\hline
\end{tabular}

Note: Source: Adapted from Zimmerman (1998).

practices, character development and academic performance. The findings of this study will have serious implication for academic advising and tutoring particularly in the higher institutions of learning.

\subsection{Statement of Objectives}

1) To ascertain relationship between time management practices, character development and academic performance.

2) To ascertain the mediating role of character development in the relationship between time management practices and academic performance.

\subsection{Research Hypotheses}

1) Time management practices will significantly predict character development.

2) Time management practices will significantly predict academic performance.

3) Character development will significantly predict academic performance.

4) Character development will mediate the relationship between time management practices and academic performance.

\section{Literature Review}

\subsection{Time Management and Academic Performance}

Time may be described as a measure of the duration and order of events in the past, the present and the future. Although every individual has 24 hours of time at his/her disposal each day, it is the effective use of time that distinguishes achievers from non-achievers in all spheres of life. Students' time management practices and personal development have been the research interests of educational researchers (Britton \& Tesser, 1991; Zimmerman, 1998) in time past. Although time management have been empirically linked with academic performance (Britton \& Tesser, 1991; Sevari \& Kandy, 2011; Yilmaz, Yoncalik, \& Bektaş, 2010), there is a dearth of empirical literature on the impact of time management practices on character development and the link between such characters and academic performance.

Al Khatib (2014) asserted that past researchers have found time management as one of the predictors of students' academic performance and achievement. In his study of 352 college students from Al Ain University of Science and Technology, UAE, he found that time management skill level explained 26 percent of total variance in the grade point average. Similarly, Misra and McKean (2000) reported a relation between time management, stress reduction and academic success. Also, Balduf, (2009) associated students' poor time management with academic underachievement.

Pehlivan (2013) reported a positive significant relation between students' grade point averages and the time 
attitudes and long-range planning sub-dimensions of time management questionnaire. Talib (2012) found academic competence, test competence, time management and test anxiety to be significantly related to student's academic performance in a sample of 199 university students from Rawalpindi and Islamabad Universities.

\subsection{Time Management, Character Development and Academic Performance}

Although there is a dearth of empirical literature on the relationship between time management, character development and academic performance, Davidson and Lickona (2007) conceptualized character to include moral character and performance character. In their definition, moral character involves values that enable persons to be of good and ethical behaviours such as integrity, justice, caring, respect, and cooperation. These characters foster interpersonal relationship and harmony among groups of persons.

Durlak, Weissberg and Pachan (2010) in their meta-analysis of 69 different after-school programs aimed at enhancing personal and social skills of children and adolescents found that skills-building program impacted upon positive social behaviours and academic achievement. Similarly, Berkowitz and Bier (2007) reviewed literature on 33 effective character education programs and found that character education programs to exert significant influence on improved school behaviour and academic achievement and grades. Furthermore, Benninga, Berkowitz, Kuehn and Smith (2003) studied the impact of character education on academic performance among schools. They found schools implementing character education to record higher academic performance than their counterparts.

Performance characters on the other hand refer to values that promote excellence in individuals' fields of endeavours such as academics, sports, occupation across lifespan. Examples of performance character include diligence, discipline and responsibility among others. Davidson and Lickona (2007) also noted that secondary school teachers identified performance characters that impact upon academic excellence to include diligence, perseverance, dependability, responsibility, orderliness, setting goals and monitoring progress toward those goals. Likewise, Berkowitz and Bier (2004) as cited in Silay (2013) associated character education with academic motivation and objectives, academic success, self-efficacy, self-control, responsibility and self-respect among others. Wolfe and Johnson (1995) also found self-discipline to predict college students' grade point averages more accurately than SAT scores. The efficient demonstration of these performance characters may be associated with effective time management. By implication, the specific character that is related to time management and academic performance is the performance character which involves the pursuit of excellence. The proposed relationship is illustrated in the in Figure 1:

This conceptual model was based on the Stimulus-Organism-Response (S-O-R) model proposed by Woodworth (1928) as cited in Baron and Kenny (1986). The model suggests that the stimulus (time management

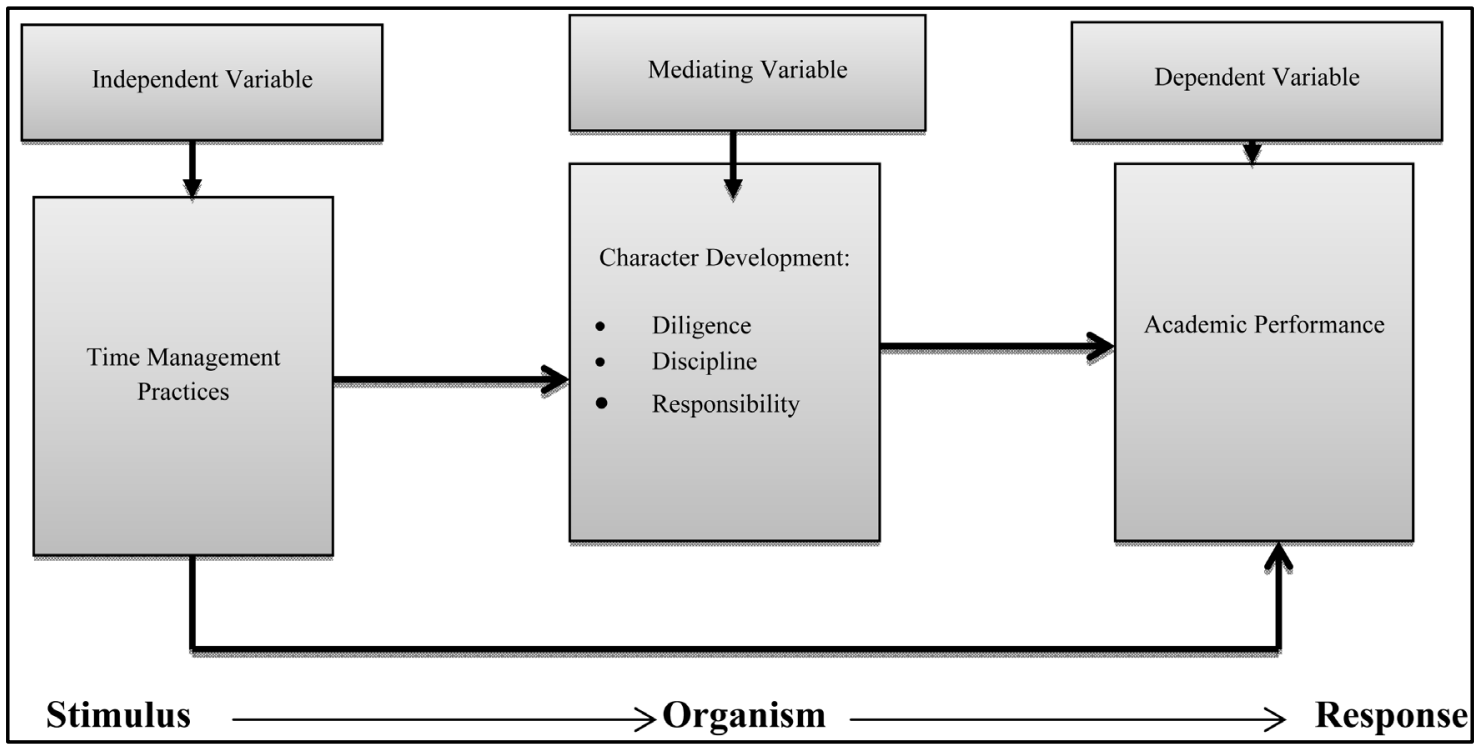

Figure 1. Conceptual framework. 
practices) elicits the response (academic performance) through influence of certain characteristics within the organism (character development). This type of relationship is referred to as meditation, in which character development is proposed to mediate the relationship between time management practices and academic performance. However, according to Baron and Kenny (1986), the three conditions that must be fulfilled before the proposed mediation relationship can occur include:

1) Time management practices must be significantly related to character development;

2) Character development must be significantly related to academic performance;

3) Time management practices must not be significantly related academic performance when character development is included.

Mediation can be complete or partial. Complete mediation occurs in a situation where the relationship between the independent variable (time management practices) and the dependent variable (academic performance) becomes zero when the mediator (character development) was controlled; but in situation where such relationship merely reduces, partial correlation has occurred.

\section{Method}

The research design employed in this study is a case study and ex-post facto design. It is a case study design because it focused on students of the Leadership Development, Covenant University. On the other hand, the expost facto design was also employed because the proposed relationship between the variables of interest had occurred prior to this study.

The participants were 120 Diploma and Certificate students of Leadership Development between the ages of 16 and 24 years old, with $29.8 \%$ being males and $70.2 \%$ being females. These include students from all levels except sophomores who were yet to have a CGPA at the time this study was conducted.

The instruments used in this study include 18-item Time Management Questionnaire (TMQ) developed by Britton and Tesser (1991) and the Character Development Questionnaire (CDQ) developed by the researcher for the purpose of this study. The TMQ from the current study has a Cronbach alpha of .79. A five point Likert format with responses ranging from Always (4), Often (3), Occasionally (2), Rarely (1) and Never (0) was used to capture participants responses on this scale.

The CDQ is a 10 item measure of dimensions performance character which includes Diligence, Discipline and Responsibility. The Diligence dimension has a Cronbach alpha of .68, Discipline has a Cronbach alpha of .62 and Responsibility dimension has a Cronbach alpha of .76. However, the complete CDQ has a Cronbach alpha of .83. The item ratings was obtained from a five point likert format with responses ranging from Always (4), Often (3), Occasionally (2), Rarely (1) and Never (0).

Students' academic performance was measured using self-reported CGPA of the last semester. The questionnaire was administered individually to consenting students after their lecture period and retrieved immediately for analysis. Participants were encouraged to seek clarification where necessary and respond to questionnaire items with all candour.

\section{Analyses and Results}

The correlations among variables are reported in Table 2. All the dimensions of time management practices were found to be positively related with all the dimensions of character development. Likewise, total character development and the diligence dimension were found to be positively related to academic performance (CGPA), while the dimensions of discipline and responsibility had no significant relationship with academic performance (CGPA). Finally no significant relationship was found between the dimensions of time management practices and academic performance (CGPA). See Table 2.

The result of the relationship among variables provides the clue into further associations among the variables. It is on this premise that the research hypotheses are tested, and the results are as follows:

H1: Time management practices will significantly predict character development.

This hypothesis was tested and confirmed using multiple regression analysis. The result of multiple regression analysis in Table 3 showed that time management predicted character development $[\mathrm{F}(3,116)=12.383, p<.01]$. The result revealed that time management explained $24.1 \%$ variance in character development $\left(\mathrm{R}^{2}=.241, p<.01\right)$; specifically, long range planning had the greatest impact on character development $(\beta=.339, p<.01)$ followed by time attitude $(\beta=.171, p=.05)$. However, short range planning had no significant impact on character 
Table 2. Correlations among variables.

\begin{tabular}{|c|c|c|c|c|c|c|c|c|c|}
\hline Variables & 1 & 2 & 3 & 4 & 5 & 6 & 7 & 8 & 9 \\
\hline Tym mgt total & 1 & & & & & & & & \\
\hline LRP & $.68^{* *}$ & 1 & & & & & & & \\
\hline TA & $.60^{* *}$ & $.37^{* *}$ & 1 & & & & & & \\
\hline SRP & $.86^{* *}$ & $.36^{* *}$ & $.27^{* *}$ & 1 & & & & & \\
\hline Cht total & $.44^{* *}$ & $.44^{* *}$ & $.33^{* *}$ & $.29^{* *}$ & 1 & & & & \\
\hline Dili & $.34^{* *}$ & $.33^{* *}$ & $.21^{*}$ & $.25^{* *}$ & $.82^{* *}$ & 1 & & & \\
\hline Disi & $.49^{* *}$ & $.46^{* *}$ & $.40^{* *}$ & $.32^{* *}$ & $.73^{* *}$ & $.48^{* *}$ & 1 & & \\
\hline Resp & $.32^{* *}$ & $.36^{* *}$ & $.22^{*}$ & $.19^{*}$ & $.83^{* *}$ & $.57^{* *}$ & $.47^{* * *}$ & 1 & \\
\hline CGPA & .18 & .17 & .04 & .15 & $.23^{*}$ & $.33^{* *}$ & .07 & .14 & 1 \\
\hline
\end{tabular}

Note: Correlation is significant at ${ }^{*} p<.05$ and ${ }^{* *} p<.01$.

Table 3. Coefficient of multiple regressions (dimensions of time management practices and character development).

\begin{tabular}{ccccccccc}
\hline & $\mathrm{R}$ & $\mathrm{R}^{2}$ & $\mathrm{~F}$ & $p$ & $\beta$ & $\mathrm{t}$ & Sig. \\
\hline Long range planning & .491 & .241 & 12.383 & $<.01$ & .339 & 3.754 & .000 \\
Time attitude & & & & & .171 & 1.946 & .054 \\
Short range planning & & & & & .119 & .1362 & .176 \\
\hline
\end{tabular}

development $(\beta=.119, p>.05)$. See Table 3 .

H2: Time management practices will significantly predict academic performance.

This hypothesis was tested using multiple regression analysis but result as shown in Table 4 revealed no significant impact of time management practices on academic performance $[\mathrm{F}(3,116)=1.628, p>.05]$. The different dimensions of time management practices had no significant impact on academic performance. The result of the multiple regression analysis confirmed the results of Pearson correlation coefficients among these variables (long range planning, $\mathrm{r}=.17, p>.05$; short range planning, $\mathrm{r}=.15, p>.05$; and time attitude, $\mathrm{r}=.04$, $p>$.05). See Table 4 .

H3: Character development will significantly predict academic performance.

This hypothesis was tested and confirmed using multiple regression analysis. The result as shown in Table 5 revealed that total character development predicted academic performance $[\mathrm{F}(3,116)=5.412, p<.01]$. However, only the dimension of diligence had significant impact on character development $(\beta=.409, p<.01)$. See Table 5.

H4: Character development will mediate the relationship between time management practices and academic performance.

This hypothesis was not confirmed since the result in Table 2 showed that no relationship existed between time management practices and academic performance $(r=.18, p>.05)$. There was no need to test for mediation since the result showed no significant relationship between the independent variable (time management practices) and the dependent variable (academic performance).

\section{Discussion, Recommendation and Conclusion}

The results of this study revealed that students’ long range planning, short range planning and time attitude did not separately and jointly predict their academic performance in terms of CGPA. There was no significant relationship between time management practices and students' CGPA. This result was supported by the findings of Yilmaz et al. (2010) who found no significant relationship between the time management behaviour and GPA among 271 students attending sports management programs at Gazi, Muğla and Atatürk Universities. This result suggests that other variables (such as anxiety, IQ and stress) may mediate or moderate the relationship between time management practices and academic performance. 
Table 4. R square and ANOVA results.

\begin{tabular}{cc}
\hline R & R and ANOVA \\
R square & .201 \\
Adjusted R square & .040 \\
Std. error of estimate & .016 \\
$\mathrm{~F}$ & .957 \\
Sig. & 1.628 \\
\hline
\end{tabular}

Table 5. Coefficient of multiple regressions (dimensions of character development and academic performance).

\begin{tabular}{cccccccc}
\hline & $\mathrm{R}$ & $\mathrm{R}^{2}$ & $\mathrm{~F}$ & $p$ & $\beta$ & $\mathrm{t}$ & Sig. \\
\hline Responsibility & .350 & .123 & 5.412 & $<.01$ & -.043 & -.396 & .693 \\
Discipline & & & & & -.109 & -1.061 & .291 \\
Diligence & & & & & 409 & .3 .704 & .000 \\
\hline
\end{tabular}

The findings of this study also revealed a significant positive relationship between time management practices and character development. The three dimensions of time management practices were found to predict overall character development and the specific dimensions of this construct (diligence, discipline and responsibility). One unifying factor may be the fact that both time management practices and performance characters are dependent on individuals' self-regulating processes and motivation. This implies that effective time management practices and the demonstration of performance characters are inspired same motivation mechanisms and drive. Over time students develop performance characters from engaging in time management practices in their quest for academic excellence.

Interestingly, the findings of this study further revealed a significant positive relationship between character development and academic performance. The result showed that the diligence dimension of character development predicted academic performance, whereas the dimensions of discipline and responsibility did not have significant relationship with students' academic performance. This is contrary to the findings of Wolfe and Johnson (1995) who reported that self-discipline predicted college students' grade point averages more accurately than did their SAT scores. Similarly, Duckworth and Seligman (2006) found self-discipline to be a stronger predictor than IQ of students' academic grades, school attendance, hours spent doing homework, and acceptance into highly competitive high schools. One would expect that all the dimensions of character development would predict academic performance, particularly because these dimensions significantly correlate with one another in this study. However, this result goes to show that certain other variables may mediate the relationship between performance characters and academic performance.

In conclusion, since time management practices and character development are correlates, both are important for academic excellence among students. Through academic advising and tutoring, students can be trained on effective time management practices which will also impact upon the development of performance characters needed for excellent academic performance. It is therefore recommended that time management training be incorporated into academic advising and tutoring among university undergraduates. This will enable Universities to better achieve their goal of producing graduates who are worthy in character and in learning. Since time management practices impacts on the development of performance character without necessarily affecting their ethical behaviours, it is imperative that future researches investigate the relationship between performance character and moral character since both are indispensible in the development of the total man.

\section{References}

Al Khatib, A. S. (2014). Time Management and Its Relation to Students' Stress, Gender and Academic Achievement among Sample of Students at Al Ain University of Science and Technology, UAE. International Journal of Business and Social Research (IJBSR), 4, 47-58. 
Balduf, M. (2009). Underachievement among College Students. Journal of Advanced Academics, 20, 274-294. http://dx.doi.org/10.1177/1932202X0902000204

Baron, R. M., \& Kenny, D. A. (1986). The Moderator-Mediator Variable Distinction in Social Psychological Research: Conceptual, Strategic and Statistical Considerations. Journal of Personality and Social Psychology, 51, 1173-1182. http://dx.doi.org/10.1037/0022-3514.51.6.1173

Benninga, J. S., Berkowitz, M. W., Kuehn, P., \& Smith, K. (2003). The Relationship of Character Education Implementation and Academic Achievement in Elementary Schools. Journal of Research in Character Education, 1, 19-32.

Berkowitz, M. W., \& Bier, M. C. (2007). What Works in Character Education. Journal of Research in Character Education, 5, 29-48.

Britton, B. K., \& Tesser, A. (1991). Effects of Time-Management Practices on College Grades. Journal of Educational Psychology, 83, 405-410. http://dx.doi.org/10.1037/0022-0663.83.3.405

Davidson, M., \& Lickona, T. (2007). Smart and Good: Integrating Performance Character and Moral Character in Schools. https://www2.cortland.edu/dotAsset/255922.pdf

Davidson, M., Khmelkov, V., \& Baker, K. (2011). Sustainability and Enduring Impact: Shaping an Intentional Culture of Excellence and Ethics. Journal of Character \& Leadership Integration, 2, 35-50.

Durlak, J. A., Weissberg, R. P., \& Pachan, M. (2010). A Meta-Analysis of After-School Programs That Seek to Promote Personal and Social Skills in Children and Adolescents. American Journal of Community Psychology, 45, $294-309$. http://dx.doi.org/10.1007/s10464-010-9300-6

Misra, R., \& McKean, M. (2000). College Students’ Academic Stress and Its Relation to Their Anxiety, Time Management, and Leisure Satisfaction. American Journal of Health Studies, 16, 41-51.

Oredein, A. O. (n.d). Checking Examination Malpractice in Nigerian Schools. http://www.naere.org.ng/journal/checking_examination_malpractice_nigerian_schools.pdf

Pehlivan, A. (2013). The Effect of the Time Management Skills of Students Taking a Financial Accounting Course on their Course Grades and Grade Point Averages. International Journal of Business and Social Science, 4, 196-203.

Sevari, K., \& Kandy, M. (2011). Time Management Skills Impact on Self-Efficacy and Academic Performance. Journal of American Science, 7, 720-726.

Silay, N. (2013). Character Education at Universities. Journal of Education and Social Research, 3, 43-50.

Talib, N. (2012). Determinants of Academic Performance of University Students. Pakistan Journal of Psychological Research, 27, 265-278.

Wolfe, R., \& Johnson, S. (1995). Personality as a Predictor of College Performance. Educational and Psychological Measurement, 55, 177-185. http://dx.doi.org/10.1177/0013164495055002002

Yilmaz, İ., Yoncalik, O., \& Bektaş, F. (2010). Relationship between the Time Management Behaviour and Academic Success. E-Journal of New World Sciences Academy, 5, 187-194.

Zimmerman, B. J. (1998). Academic Studying and the Development of Personal Skill: A Self-Regulating Perspective. Educational Psychology, 33, 73-86. http://dx.doi.org/10.1080/00461520.1998.9653292 
Scientific Research Publishing (SCIRP) is one of the largest Open Access journal publishers. It is currently publishing more than 200 open access, online, peer-reviewed journals covering a wide range of academic disciplines. SCIRP serves the worldwide academic communities and contributes to the progress and application of science with its publication.

Other selected journals from SCIRP are listed as below. Submit your manuscript to us via either submit@scirp.org or Online Submission Portal.
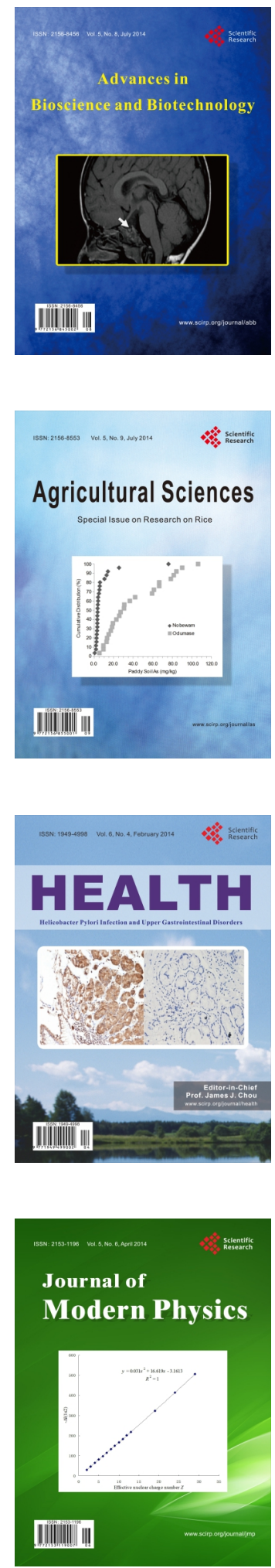
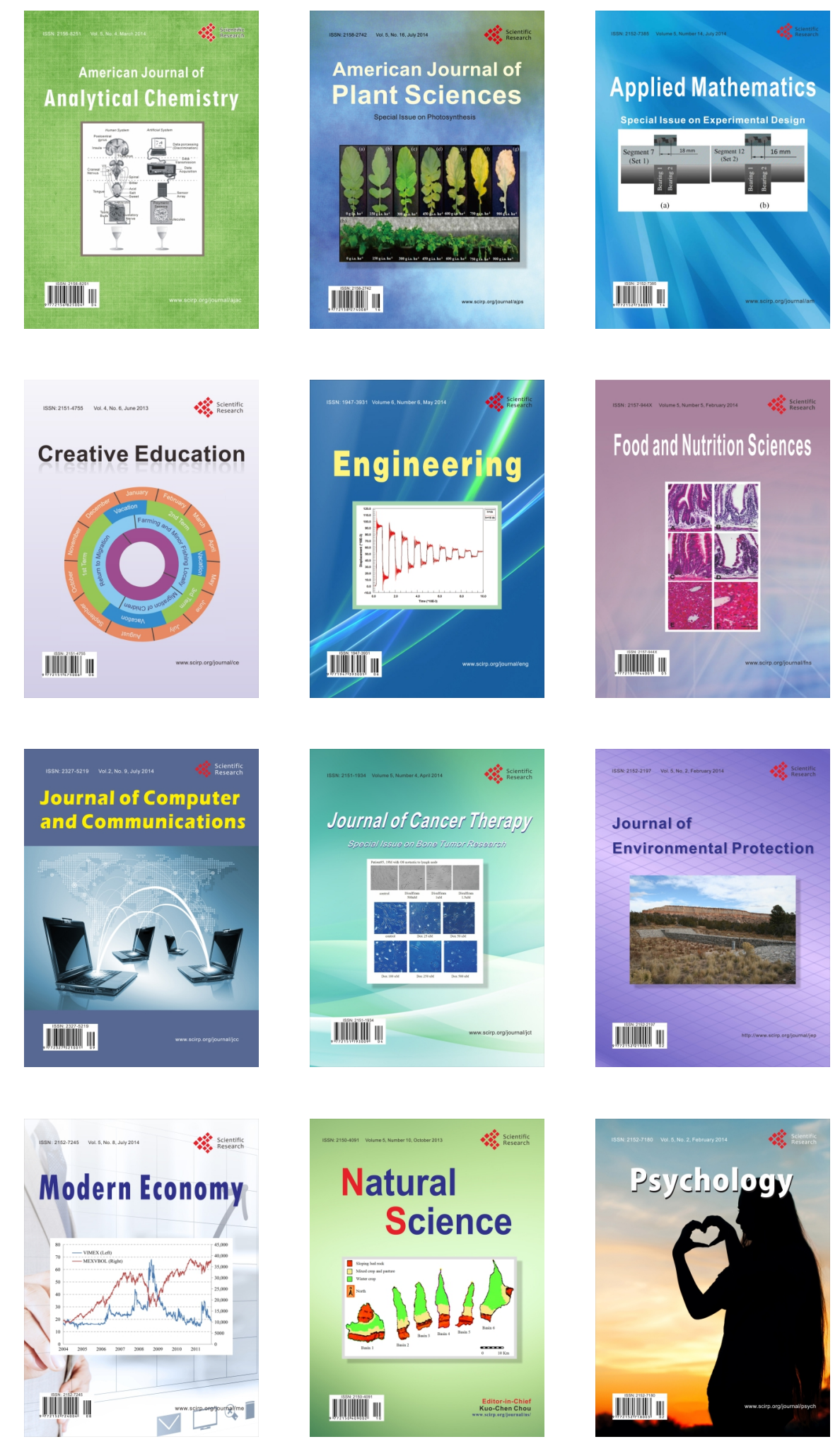